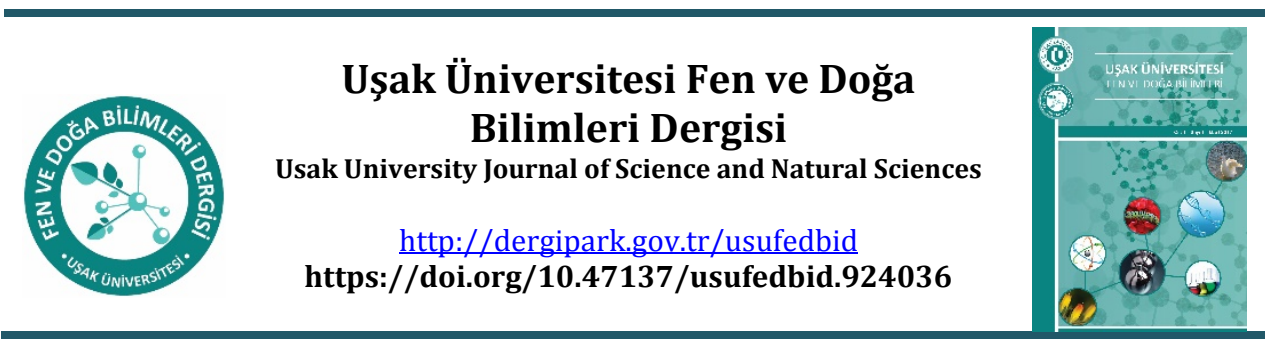

Araştırma Makalesi

\title{
Analysis of Dentistry Faculty in terms of Occupational Safety and Health: Risk Assessment Example
}

\author{
Yağmur ERDAL ${ }^{1 *}$, Ayşe ÖZDEMİR \\ ${ }^{1}$ Department of Occupational Health and Safety, Institute of Science and Technology, Ușak University, Ușak, \\ Turkey \\ ${ }^{2}$ Department Of Basic Medical Sciences (Medicine), Faculty of Medicine, Usak University, Usak, Turkey
}

Geliș: 21 Nisan 2021

Kabul: 27 Temmuz 2021 / Received: 21 April 2021

Accepted: 27 July 2021

\begin{abstract}
Risk management, which has an important place in the criteria of the Ministry of Health Quality Standards in Health, is a guide in terms of preventing or minimizing the other risks identified regarding the safety of patients, relatives, visitors, employees, facilities and environment and services provided in the hospital. As a result of research conducted in the health sector, many chemical, physical, ergonomic and biological hazards are encountered in this area at the same time. In recent years, the increased workload combined with the ease of access to the health sector has created an additional source of danger, as well as the inclusion of patients and their relatives in the current risks. In this study, we tried to determine the existing or potential risks by performing a risk analysis in a dentistry faculty. In the evaluation, a total of 47 risks and the hazards that cause these risks, 20 of which are at significant level, 26 of which are at medium level and 1 of which is at an intolerable level, and the precautions to be taken for each risk are specified. Considering the identified risks and recommended measures, the improvements to be made play an important role in increasing the service quality by providing significant positive results in patient and employee safety.
\end{abstract}

Keywords: Risk analysis, employee safety, dentistry.

\section{Özet}

Sağlık Bakanlığı Sağlıkta Kalite Standartları kriterlerinde önemli bir yere sahip olan risk yönetimi hasta, hasta yakını, ziyaretçi, çalışan, tesis ve çevre güvenliği ile hastanede sunulan hizmetlere ilişkin tanımlanan diğer risklerin önlenmesi veya kaynağında mücadele edilerek en az seviyeye indirilmesi açısından yol gösterici olmaktadır. Sağlık sektöründe yapılan araștırmalar sonucunda ise, bu alanda kimyasal, fiziksel, ergonomik, biyolojik birçok tehlike ile aynı anda karşılaşılmaktadır. Son yıllarda sağlık sektörüne ulaşımın kolaylaşması ile beraber artan iş yükünün de ekstra bir tehlike kaynağı yaratmasının yanı sıra, mevcut risklere hasta ve yakınlarının da dahil olmasına neden olmuştur. Yaptığımız bu çalışmada ise bir diș hekimliği fakültesinde risk analizi yapılarak mevcut olan ya da olabilecek riskler belirlenmeye çalışılmıştır. Yapılan değerlendirmede 20'si önemli düzeyde, 26'sı orta düzeyde ve 1'i tolere edilemez düzeyde olmak üzere toplam 47 risk ve buna neden olan tehlikeler tespit edilmiş olup her risk için alınması gereken önlemler belirtilmiștir. Belirlenen riskler ve önerilen önlemler dikkate alındığında yapılacak olan iyileştirmeler hasta ve çalışan güvenliğinde önemli olumlu sonuçlar sağlayarak hizmet kalitesinin de arttırılmasında önemli rol oynamaktadır.

Anahtar Kelimeler: Risk analizi, çalışan güvenliği, diş hekimliği.

*Corresponding author:

E-mail: yagmur_erdal@hotmail.com (ORCID ID: 0000-0003-0528-4236)

(C)2021 Usak University all rights reserved. 


\section{Introduction}

Although the concepts of Health and safety seem to be two different concepts, they are actually related concepts. When we consider that the concept of safety is related to situations that cause injury, and health is related to conditions that cause disease, it describes a situation that endangers human life in two concepts. For example, when we consider the concept of stress, stress is a danger that can cause both psychological and physiological problems over a long period of time, i.e. a health problem. However, an over-stressed worker may be more prone to unintentionally forgetting safety measures and therefore causing an accident. In this case, stress is a safety concern. It is at this point that the concept of Occupational Health and safety comes into play to create a wide working area covering the concepts of Health and safety. Occupational safety and health is a multi-disciplinary field including many fields such as medicine, engineering and law. As a result of long-lasting studies conducted by scientists coming from different fields, it has become a scientific branch by passing through many stages from the past to the present [1].

Health sector is one of the most important fields of study in occupational safety and health. In a report by National Institute for Occupational Safety and Health (NIOSH), it was stated that there are risks in the health sector arising from chemical hazards such as disinfections, sterilants, anaesthetics and drugs, and also risks arising from physical hazards such as thermal comfort conditions, ergonomic hazards and workload [2]. Although these risks are seen as common risks in the working environment, it should be remembered that there are risks specific to each unit. Therefore, risk assessment is one of the important building blocks of occupational safety and health. Preparing an accurate risk assessment is an important step in preventing possible dangers by detecting the presence of danger with a pro-active approach. Although the main dangers that can be encountered in the working environment are biological, chemical, physical, ergonomic and psychosocial risks, the severity of these risks may differ according to working areas, occupational groups and the work done. These risk groups and their severity also differs according to each unit in dentistry.

In addition to physical and chemical hazards, biological hazards are also important risk factors for health workers. Agents not visible to the naked eye can be dangerous even at extremely low concentrations. Even if no biological agent is detected, it is possible that microorganisms can produce a toxic or allergic effect through their metabolites (mycotoxins or component endotoxins). Unlike other hazardous substances, biological agents multiply. Under favorable conditions, a small number of microorganisms can multiply in a very short time, creating a significant problem [3].

While biological risks are the most important source of risk that may occur in this sector, they also cause serious illnesses for healthcare professionals, other professionals in hospital, patients and patient relatives. These infections can be examined in the form of infections transmitted by respiratory tract, droplet, blood and body fluids. Amalgam, which is used as a filling material in filling treatments, is a chemical substance that has caused controversy for years. Amalgam, which contains elemental mercury, has little or no toxic effect when swallowed during procedure since $0.01 \%$ of it is absorbed from the gastrointestinal system [4]. When inhaled at high concentrations, it may cause pneumonia and noncardiogenic pulmonary edema and gingivostomatitis in the lungs, as well as causing abdominal pain and hemorrhagic gastroenteritis, intestinal necrosis, acute tubulary neurosis, shock and death when taken acutely orally [5]. 
Physical risks can be examined under the headings of noise, vibration, radiation and ergonomy. In the hospital environment, the sounds of doors slamming, telephone sounds, machine and tool sounds, the sounds of objects falling down, the sounds of broken tools can cause noise; devices with high frequency and strong vibration spectrums can cause mechanical vibration; working with materials such as acrylic and ceramic used in laboratories can cause dusty air in the environment and inhaling this dust can cause accumulation in the lungs. In addition to making a diagnosis, lasers which are used in dentistry for treatment cause exposure to low and moderate intensity radiation [6]. Dentists are more exposed to ergonomic risks since their working area is a narrow area like the inside of the mouth, they make repetitive movements which require strength, they have to be fixed in the same position for a long time due to the nature of their treatment, and due to reasons such as the mechanical vibration they are exposed to resulting from the hand devices they use [7]. The causes of ergonomic problems that result in musculoskeletal disorders are due to the environment studied or the nature of the work performed November. In its assessments of health workers, the National Institute for Occupational Safety and health (NIOSH) found that sprains and strain are the most common causes of November musculoskeletal disorders [8]. November-the second most common type of decongestant is low back pain, which is one of the disorders of the musculoskeletal system, and is the second most common among diseases affecting the production process in developed countries. Decelerating for a long time during working hours, lifting heavy loads, making the body November muscles perform challenging movements are among the most common causes of injury. A study conducted in Turkey on nurses and medical personnel found that the frequency of low back pain ranged from 39.9 to $69.0 \%$ Dec [9].

Being faced with all these risks and also trying to cope with the difficulties and responsibilities of the job bring along stress. Therefore, stress factor can also be considered as another risk factor in the field of dentistry. In a study conducted by Myers and Myers, it was found that the main factor driving dentists to stress was lagging behind working program. In a study conducted on 2441 dentists, $70.4 \%$ of whom were male and $29.6 \%$ of whom were female, the most stressed group was found to be the dentists who had children younger than 18. It was also found that personal factors such as alcohol, sleeplessness, smoking, eating and exercise disorder were among the factors which caused occupational stress. It was also found in the same study that employees exposed to excessive stress had symptoms such as nervousness, tension, headache and fatigue [10].

\section{Determination and Analysis of Risks}

According to the Article 9 of Occupational Safety and Health Assessment Regulation, two methods are taken into consideration while determining and analysing risks. These are quantitative and qualitative methods. Quantitative risk analysis uses numerical methods to calculate the risks, gives numerical values to factors such as the probability of threat and the effects of the threat and finds the risk value by processing these values with mathematical and logical methods. On the other hand, qualitative risk analysis uses descriptive values such as high and very high instead of numerical values while calculating and expressing risk [11]. 


\section{Material Method}

\subsection{Type Matrix}

5 x 5 Matrix diagram (L Type Matrix), which is especially used in cause and effect assessments, is used very frequently since it is simple and easy to understand. It is not sufficient by itself for all the works with a complex structure and different processes; however, it can be used in situations that require urgency and need precautions as soon as possible in such enterprises. In this case, the success rate of the analysis made according to the analyst's level of knowledge and experience varies [12]. Risk score is obtained by multiplying the degree of probability and loss and noted down in the table. If the possibility of the occurrence of an event is almost none, its probability is evaluated as very small (1), if the possibility is once a year it is evaluated as small (2), if it is a few times a year, it is evaluated as medium (3), if the possibility is often, its probability is evaluated as high (4) and if its possibility of occurrence is very often, its probability is evaluated as very high (5).

Table 1. Probability rating table

\begin{tabular}{|c|c|}
\hline PROBABILITY & RATING STEPS FOR THE PROBABILITY OF EMERGENCE \\
\hline $\begin{array}{c}\text { VERY SMALL } \\
\text { (1) }\end{array}$ & Hardly ever \\
\hline SMALL & Very small (once a year), only in abnormal situations \\
\hline (2) & Small (a few times a year) \\
\hline (3) & Often (once a month) \\
\hline HIGH & \\
\hline (4) & conditions \\
\hline (5ERY HIGH & Very often (once a week, everyday), under normal working \\
\hline
\end{tabular}

When an incident occurs, if the consequence is a situation which does not cause loss of working hour and which requires first aid, it is stated as very mild (1), as mild (2) if there is no working day loss, no permanent effect and which requires outpatient care or first aid, as moderate (3) if it requires inpatient care, as significant (4) if it can cause serious injury, long term treatment and occupational disease and very significant (5) if it causes death and permanent incapacity. 
Table 2. Severity rating table

\begin{tabular}{|c|c|}
\hline CONSEQUENCE & RATING \\
\hline $\begin{array}{c}\text { VERY MILD } \\
\text { (1) }\end{array}$ & No working hour loss, requires first aid \\
\hline $\begin{array}{c}\text { MILD } \\
\text { (2) }\end{array}$ & $\begin{array}{c}\text { No working day loss, no permanent impact, requires } \\
\text { outpatient care or first aid }\end{array}$ \\
\hline $\begin{array}{c}\text { MODERATE } \\
\text { (3) }\end{array}$ & Mild injury, requires inpatient care \\
\hline $\begin{array}{c}\text { SIGNIFICANT } \\
\text { (4) }\end{array}$ & Serious injury, long term treatment, occupational disease \\
\hline $\begin{array}{c}\text { VERY } \\
\text { SIGNIFICANT } \\
\text { (5) }\end{array}$ & Death, permanent incapacity \\
\hline
\end{tabular}

After determining the probability of occurrence of an event and the degree of its severity if it occurs, risk score table is used to evaluate the situation.

Table 3. Risk Score = Probability $\mathrm{x}$ Degree of loss

\begin{tabular}{|l|l|l|l|l|l|}
\hline $\begin{array}{l}\text { RISK SCORE } \\
\text { MATRIX }\end{array}$ & \multicolumn{5}{l}{ PROBABILITY } \\
\hline & 1 & 2 & 3 & 4 & 5 \\
SEVERITY & Very low & Low & Medium & High & Very high \\
\hline 1 & Insignificant & Low & Low & Low & Low \\
Very mild & 1 & 2 & 3 & 4 & 5 \\
\hline 2 & Low & Low & Low & Medium & Medium \\
Mild & 2 & 4 & 6 & 8 & 10 \\
\hline 3 & Low & Low & Medium & Medium & High \\
Moderate & 3 & 6 & 9 & 12 & 15 \\
\hline 4 & Low & Medium & Medium & High & High \\
Significant & 4 & 8 & 12 & 16 & 20 \\
\hline 5 & Low & Medium & High & High & Intolerable \\
Very significant & 5 & 10 & 15 & 20 & 25 \\
\hline
\end{tabular}

According to the data obtained in the risk score, the severity and probability of the hazard were evaluated and the acceptability of the risk and the measures to be taken are given in the table below [12]. 
Table 4. Acceptability values

\begin{tabular}{|c|c|}
\hline $\begin{array}{l}\text { DEGREE OF } \\
\text { ACCEPTABILITY }\end{array}$ & MEASURES TO BE TAKEN \\
\hline $\begin{array}{l}\text { Intolerable risk } \\
25\end{array}$ & $\begin{array}{l}\text { - On-going activities should be stopped immediately. } \\
\text { - Activities should not be started until the risks } \\
\text { become acceptable. } \\
\text { - If the risk does not decrease although measures have } \\
\text { been taken, the work performed should be cancelled. }\end{array}$ \\
\hline $\begin{array}{l}\text { Significant Risk } \\
15-16-20\end{array}$ & $\begin{array}{l}\text { - Any on-going activities should be stopped without } \\
\text { delay. } \\
\text { - Works should not be started until the risk } \\
\text { determined is decreased. } \\
\text { - If the risk continues with the work, measures should } \\
\text { be taken quickly and decisions should be made } \\
\text { about whether to continue the work according to the } \\
\text { results of the measure. }\end{array}$ \\
\hline $\begin{array}{l}\text { Medium risk } \\
8-9-10-12\end{array}$ & $\begin{array}{l}\text { - Measures should be started to decrease the risk. } \\
\text { - Measures taken to decrease the risk may take some } \\
\text { time. }\end{array}$ \\
\hline $\begin{array}{l}\text { Acceptable } \\
\text { Risk } \\
2-3-4-5-6\end{array}$ & $\begin{array}{l}\text { - There may not be a need to take extra measure to } \\
\text { eliminate the risks. } \\
\text { - Sustainability of the existing risks should be } \\
\text { controlled. }\end{array}$ \\
\hline $\begin{array}{l}\text { Insignificant } \\
\text { Risk } \\
1\end{array}$ & $\begin{array}{l}\text { - There may be no need to take measures for the } \\
\text { existing risks or to protect the records of the } \\
\text { measures taken. }\end{array}$ \\
\hline
\end{tabular}




\section{Results}

In this section, the risk analysis applied in Uşak University Faculty of Dentistry was evaluated according to $L$ type matrix model and presented in tables. In this evaluation, a total of 47 risks, 15 at significant level, 30 at medium level and 2 at acceptable level, and hazards causing these risks were found and the measures that should be taken for each risk were stated.

Potential hazards and risks found as a result of the evaluation made in the risk analysis table prepared are given below.

Table 5. Dentistry Faculty Risk Assessment Table

\begin{tabular}{|c|c|c|c|c|}
\hline No & Hazard & Risk & Risk Score & Measures to be taken \\
\hline 1 & Drugs & $\begin{array}{l}\text { Adverse } \\
\text { reactions }\end{array}$ & $\begin{array}{c}3 \times 3=9 \\
\text { Moderate }\end{array}$ & $\begin{array}{l}\text { Training of the healthcare } \\
\text { personnel, establishing } \\
\text { the system to take the } \\
\text { necessary measures in } \\
\text { emergency situations, } \\
\text { taking a good anamnesis } \\
\text { to review the patient's } \\
\text { health problems. }\end{array}$ \\
\hline 2 & $\begin{array}{l}\text { Body fluids and } \\
\text { blood }\end{array}$ & Infection & $\begin{array}{c}4 \times 4=16 \\
\text { High }\end{array}$ & $\begin{array}{l}\text { To make sure that the } \\
\text { personnel uses personal } \\
\text { protective equipment } \\
\text { while working (gloves, } \\
\text { protective face barrier, } \\
\text { mask, goggles, water proof } \\
\text { barrier apron), the } \\
\text { equipment used should be } \\
\text { good quality and fit for } \\
\text { purpose, controls should } \\
\text { be made for the stock of } \\
\text { materials. }\end{array}$ \\
\hline 3 & $\begin{array}{l}\text { Infections } \\
\text { resulting from } \\
\text { personnel }\end{array}$ & $\begin{array}{c}\text { Labour loss, } \\
\text { occupational } \\
\text { disease }\end{array}$ & $\begin{array}{c}\text { 4x4=16 } \\
\text { High }\end{array}$ & $\begin{array}{l}\text { Practices should be known } \\
\text { and applied among } \\
\text { healthcare worker } \\
\text { patients in order to } \\
\text { prevent infection } \\
\text { transmission, practices } \\
\text { should be made to } \\
\text { increase immunity and } \\
\text { workers' vaccines should } \\
\text { be completed, suitable } \\
\text { equipment and materials } \\
\text { should be present. }\end{array}$ \\
\hline
\end{tabular}




\begin{tabular}{|c|c|c|c|c|}
\hline 4 & Noise & $\begin{array}{l}\text { Hearing loss, } \\
\text { work accident, } \\
\text { occupational } \\
\text { disease }\end{array}$ & $\begin{array}{c}3 \times 4=12 \\
\text { Medium }\end{array}$ & $\begin{array}{l}\text { Annual measurements } \\
\text { should be made, in units } \\
\text { exceeding the limit values, } \\
80 \mathrm{~dB} \text { EPE should be } \\
\text { present as a result of the } \\
\text { measurements made at } \\
\text { the source, environment } \\
\text { and the last EPE use, use } \\
\text { of EPE should be made } \\
\text { compulsory in case of } 85 \\
\text { dB. Attention should be } \\
\text { paid to the sound level in } \\
\text { the devices to be bought. }\end{array}$ \\
\hline 5 & $\begin{array}{l}\text { Electric cables on } \\
\text { the floor in } \\
\text { polyclinics, other } \\
\text { services and } \\
\text { laboratories }\end{array}$ & $\begin{array}{l}\text { Death or injury } \\
\text { as a result of } \\
\text { electric shock, } \\
\text { tripping and } \\
\text { falling }\end{array}$ & $\begin{array}{c}3 \times 4=12 \\
\text { Medium }\end{array}$ & $\begin{array}{l}\text { The cables on the floor } \\
\text { should be collected and } \\
\text { placed in a case, necessary } \\
\text { arrangements should be } \\
\text { made to prevent tripping } \\
\text { and falling, there should } \\
\text { be no cables on the floor if } \\
\text { possible. }\end{array}$ \\
\hline 6 & $\begin{array}{l}\text { Sharp object } \\
\text { injury }\end{array}$ & $\begin{array}{l}\text { Injury, } \\
\text { infection }\end{array}$ & $\begin{array}{l}3 \times 4=12 \\
\text { Medium }\end{array}$ & $\begin{array}{l}\text { Appropriate physical } \\
\text { environment should be } \\
\text { provided to workers, } \\
\text { appropriate training } \\
\text { should be given, care } \\
\text { should be taken for the } \\
\text { working environment not } \\
\text { to be messy, injectors } \\
\text { should be closed after use, } \\
\text { care should be taken while } \\
\text { getting drug, sharp objects } \\
\text { should be collected with } \\
\text { suitable methods while } \\
\text { collecting medical waste, } \\
\text { injuries should be } \\
\text { reported }\end{array}$ \\
\hline 7 & $\begin{array}{l}\text { Is waste disposal } \\
\text { carried out in } \\
\text { accordance with } \\
\text { waste regulation? }\end{array}$ & $\begin{array}{l}\text { Occupational } \\
\text { disease, public } \\
\text { health risk, } \\
\text { labour loss }\end{array}$ & $\begin{array}{c}3 \times 3=9 \\
\text { Medium }\end{array}$ & $\begin{array}{l}\text { Personnel should be } \\
\text { trained in accordance with } \\
\text { the waste regulation, } \\
\text { appropriate and trained } \\
\text { employees should be used } \\
\text { in waste disposal, all }\end{array}$ \\
\hline
\end{tabular}




\begin{tabular}{|c|c|c|c|c|}
\hline & & & & $\begin{array}{l}\text { protection measures and } \\
\text { personal protective } \\
\text { equipment should be } \\
\text { provided, suitability of } \\
\text { collection places should be } \\
\text { ensured, temperature and } \\
\text { moisture of the collection } \\
\text { places should be made, } \\
\text { collection places should be } \\
\text { controlled by the related } \\
\text { person. }\end{array}$ \\
\hline 8 & $\begin{array}{c}\text { Is waste disposal } \\
\text { carried out by } \\
\text { authorized } \\
\text { personnel? }\end{array}$ & $\begin{array}{l}\text { Occupational } \\
\text { disease, work } \\
\text { accident }\end{array}$ & $\begin{array}{l}3 \times 4=12 \\
\text { Medium }\end{array}$ & $\begin{array}{l}\text { The health of the } \\
\text { personnel should be } \\
\text { controlled at least once a } \\
\text { year, vaccines should be } \\
\text { completed, shower and } \\
\text { toilet needs should be } \\
\text { met, personal protective } \\
\text { equipment use should be } \\
\text { provided (suitable glove, } \\
\text { mask, cap, etc.), giving the } \\
\text { necessary trainings, and } \\
\text { making sure that trained } \\
\text { staff work in the disposal } \\
\text { of medical waste. }\end{array}$ \\
\hline 9 & $\begin{array}{l}\text { Infections } \\
\text { resulting from } \\
\text { patient }\end{array}$ & Infection & $\begin{array}{c}4 \times 4=16 \\
\text { High }\end{array}$ & $\begin{array}{l}\text { Practices to prevent } \\
\text { infection transmission } \\
\text { among healthcare worker } \\
\text { patients included in the } \\
\text { Turkish nosocomial } \\
\text { infections and control } \\
\text { association isolation } \\
\text { precaution guide should } \\
\text { be known and applied, } \\
\text { immunization studies and } \\
\text { vaccines of workers } \\
\text { should be completed, } \\
\text { necessary protective } \\
\text { equipment should be } \\
\text { provided for the } \\
\text { employees, routine check- } \\
\text { ups (such as blood, lung } \\
\text { tests) of the employees } \\
\text { should be made. }\end{array}$ \\
\hline
\end{tabular}




\begin{tabular}{|c|c|c|c|c|}
\hline 10 & $\begin{array}{l}\text { Are unauthorized } \\
\text { people prevented } \\
\text { from entering the } \\
\text { generator and } \\
\text { transformer } \\
\text { room? }\end{array}$ & $\begin{array}{l}\text { Work accident } \\
\text { and death }\end{array}$ & $\begin{array}{l}2 \times 5=10 \\
\text { Medium }\end{array}$ & $\begin{array}{l}\text { Only authorized } \\
\text { individuals should enter } \\
\text { the room, health and } \\
\text { safety signs and warnings } \\
\text { should be obeyed, daily, } \\
\text { weekly, monthly and } \\
\text { yearly periodic } \\
\text { maintenance of the } \\
\text { generators should be } \\
\text { made. }\end{array}$ \\
\hline 11 & $\begin{array}{l}\text { Working with X- } \\
\text { ray }\end{array}$ & $\begin{array}{l}\text { Being exposed } \\
\text { to radiation }\end{array}$ & $\begin{array}{c}5 \times 3=15 \\
\text { High }\end{array}$ & $\begin{array}{l}\text { Dosimeter follow-up of } \\
\text { the employees should be } \\
\text { made, hemogram and } \\
\text { peripheral smear, eye and } \\
\text { skin examinations should } \\
\text { be made, protective } \\
\text { equipment use should be } \\
\text { ensured (lead apron, } \\
\text { goggles, gloves, thyroid } \\
\text { protector, } \\
\text { protective screen), } \\
\text { necessary training should } \\
\text { be planned for the } \\
\text { working staff, health and } \\
\text { safety signs and warnings } \\
\text { should be obeyed }\end{array}$ \\
\hline 12 & $\begin{array}{l}\text { Is orientation } \\
\text { training given? }\end{array}$ & $\begin{array}{l}\text { Work accident, } \\
\text { injury, } \\
\text { occupation } \\
\text { disease }\end{array}$ & $\begin{array}{c}2 \times 4=8 \\
\text { Medium }\end{array}$ & $\begin{array}{l}\text { New staff should be } \\
\text { informed about the } \\
\text { equipment and devices } \\
\text { used and they should be } \\
\text { provided with basic work } \\
\text { safety and health training. }\end{array}$ \\
\hline 13 & $\begin{array}{l}\text { Communication } \\
\text { problems with } \\
\text { employees, } \\
\text { patients and their } \\
\text { relatives }\end{array}$ & $\begin{array}{c}\text { Physical and } \\
\text { verbal violence }\end{array}$ & $\begin{array}{l}4 \times 3=12 \\
\text { Medium }\end{array}$ & $\begin{array}{l}\text { Communication, stress } \\
\text { management and anger } \\
\text { management training } \\
\text { should be provided to } \\
\text { employees, psychological } \\
\text { support should be } \\
\text { provided to employees } \\
\text { when necessary, all the } \\
\text { units should be protected } \\
\text { for } 24 \text { hours with security } \\
\text { staff, areas of general use } \\
\text { should be monitored with } \\
\text { security cameras, white }\end{array}$ \\
\hline
\end{tabular}




\begin{tabular}{|c|c|c|c|c|}
\hline & & & & $\begin{array}{l}\text { code call should be } \\
\text { answered in shortest time } \\
\text { possible, white code } \\
\text { reports should be made } \\
\text { regularly, the workload of } \\
\text { employees should be } \\
\text { reduced. }\end{array}$ \\
\hline 14 & $\begin{array}{l}\text { Ergonomic } \\
\text { problems }\end{array}$ & $\begin{array}{c}\text { Muscoskeletal } \\
\text { disorders }\end{array}$ & $\begin{array}{c}5 \times 3=15 \\
\text { High }\end{array}$ & $\begin{array}{l}\text { Every practice should be } \\
\text { made in accordance with } \\
\text { the procedure and the } \\
\text { order specified in the } \\
\text { instructions, training } \\
\text { should be given about } \\
\text { ergonomy, areas for } \\
\text { ergonomic work should be } \\
\text { created and suitable } \\
\text { equipment should be } \\
\text { selected, breaks should be } \\
\text { given at appropriate } \\
\text { intervals and simple } \\
\text { exercises should be made, } \\
\text { dental chair and its angle } \\
\text { should allow the dentist to } \\
\text { work suitably. }\end{array}$ \\
\hline 15 & Vibration & $\begin{array}{l}\text { Muscoskeletal } \\
\text { disorders }\end{array}$ & $\begin{array}{c}5 \times 3=15 \\
\text { High }\end{array}$ & $\begin{array}{l}\text { Every practice should be } \\
\text { made in accordance with } \\
\text { the procedure and the } \\
\text { order specified in the } \\
\text { instructions, training } \\
\text { should be given about } \\
\text { ergonomy, areas for } \\
\text { ergonomic work should be } \\
\text { created and suitable } \\
\text { equipment should be } \\
\text { selected, breaks should be } \\
\text { given at appropriate } \\
\text { intervals and simple } \\
\text { exercises should be made, } \\
\text { dental chair and its angle } \\
\text { should allow the dentist to } \\
\text { work suitably. }\end{array}$ \\
\hline
\end{tabular}




\begin{tabular}{|c|c|c|c|c|}
\hline 16 & $\begin{array}{l}\text { Is the access of } \\
\text { unauthorized } \\
\text { personnel in the } \\
\text { sterilization area } \\
\text { prevented? }\end{array}$ & $\begin{array}{l}\text { Combustion } \\
\text { from steam } \\
\text { autoclave }\end{array}$ & $\begin{array}{c}2 \times 4=8 \\
\text { Medium }\end{array}$ & $\begin{array}{l}\text { Sterilization should be } \\
\text { made by the authorized } \\
\text { personnel, suitable EPE } \\
\text { should be used, usage } \\
\text { instructions of the devices } \\
\text { should be followed, and } \\
\text { there should be warnings. }\end{array}$ \\
\hline 17 & $\begin{array}{l}\text { Cracks in the } \\
\text { stairs }\end{array}$ & Fall, injury & $\begin{array}{l}4 \times 3=12 \\
\text { Medium }\end{array}$ & $\begin{array}{l}\text { Irregularities in the stairs } \\
\text { should be eliminated and } \\
\text { they should be controlled } \\
\text { regularly. }\end{array}$ \\
\hline 18 & $\begin{array}{l}\text { Disorganized } \\
\text { working } \\
\text { environment }\end{array}$ & Injury & $\begin{array}{c}3 \times 3=9 \\
\text { Medium }\end{array}$ & $\begin{array}{l}\text { The materials should be } \\
\text { removed after work is } \\
\text { finished in the working } \\
\text { area, there should be no } \\
\text { other materials than the } \\
\text { materials used in the } \\
\text { working areas. }\end{array}$ \\
\hline 19 & $\begin{array}{l}\text { No insulating } \\
\text { maps in front of } \\
\text { electric panels }\end{array}$ & $\begin{array}{l}\text { Death or injury } \\
\text { as a result of } \\
\text { electric shock }\end{array}$ & $\begin{array}{c}5 \times 5=25 \\
\text { Intolerable }\end{array}$ & $\begin{array}{l}\text { Insulating maps should be } \\
\text { placed in front of electric } \\
\text { panels. }\end{array}$ \\
\hline 20 & $\begin{array}{c}\text { Obstacles in front } \\
\text { of fire } \\
\text { extinguishers }\end{array}$ & $\begin{array}{l}\text { Injury or death } \\
\text { as a lack of } \\
\text { immediate } \\
\text { intervention }\end{array}$ & $\begin{array}{c}3 \times 5=15 \\
\text { High }\end{array}$ & $\begin{array}{l}\text { Obstacles in front of fire } \\
\text { extinguishers should be } \\
\text { removed }\end{array}$ \\
\hline 21 & $\begin{array}{l}\text { Obstacles in front } \\
\text { of the electric } \\
\text { panels and their } \\
\text { covers being } \\
\text { open }\end{array}$ & $\begin{array}{l}\text { Electric shock, } \\
\text { injury, death }\end{array}$ & $\begin{array}{c}3 \times 5=15 \\
\text { High }\end{array}$ & $\begin{array}{l}\text { Electric panels should be } \\
\text { locked and only the } \\
\text { authorized personnel } \\
\text { should have the key. } \\
\text { There should be no } \\
\text { obstacles in front of the } \\
\text { electric panels, insulating } \\
\text { maps should be placed. }\end{array}$ \\
\hline
\end{tabular}




\begin{tabular}{|c|c|c|c|c|}
\hline 22 & $\begin{array}{c}\text { Insufficient } \\
\text { ventilation in } \\
\text { patient waiting } \\
\text { rooms }\end{array}$ & $\begin{array}{l}\text { Not being able } \\
\text { to remove the } \\
\text { sources of } \\
\text { infection from } \\
\text { the } \\
\text { environment, } \\
\text { infectious } \\
\text { diseases }\end{array}$ & $\begin{array}{c}4 \times 5=20 \\
\text { High }\end{array}$ & $\begin{array}{l}\text { Artificial ventilation } \\
\text { systems should be used in } \\
\text { places with no natural } \\
\text { ventilation; ventilation } \\
\text { systems should be } \\
\text { controlled and cleaned } \\
\text { periodically. }\end{array}$ \\
\hline 23 & $\begin{array}{l}\text { Insufficient } \\
\text { lighting in the } \\
\text { corridors }\end{array}$ & $\begin{array}{l}\text { Tripping, } \\
\text { falling down }\end{array}$ & $\begin{array}{l}4 \times 3=12 \\
\text { Medium }\end{array}$ & $\begin{array}{l}\text { Artificial lighting should } \\
\text { be used in areas with no } \\
\text { natural lighting; this } \\
\text { lighting must be at least } \\
50 \text { lux in the corridors. }\end{array}$ \\
\hline 24 & $\begin{array}{l}\text { Parking in front } \\
\text { of the } \\
\text { warehouses } \\
\text { where medical } \\
\text { and biological } \\
\text { waste are } \\
\text { collected }\end{array}$ & $\begin{array}{l}\text { Infection, } \\
\text { infectious } \\
\text { disease }\end{array}$ & $\begin{array}{c}4 \times 4=16 \\
\text { High }\end{array}$ & $\begin{array}{l}\text { The warehouses where } \\
\text { medical and biological } \\
\text { wastes are disposed } \\
\text { should be marked, } \\
\text { suitable warning signs } \\
\text { should be put, parking } \\
\text { should be prevented in } \\
\text { front of these areas and } \\
\text { they should be } \\
\text { surrounded if necessary. }\end{array}$ \\
\hline 25 & $\begin{array}{l}\text { Beck use in } \\
\text { laboratories }\end{array}$ & Burn, injury & $\begin{array}{l}4 \times 3=12 \\
\text { Medium }\end{array}$ & $\begin{array}{l}\text { Students should be } \\
\text { informed about the use of } \\
\text { beck, suitable EPE should } \\
\text { be used to protect from } \\
\text { the flames, and broken } \\
\text { becks should not be used. }\end{array}$ \\
\hline 26 & $\begin{array}{l}\text { Natural gas used } \\
\text { in the becks in } \\
\text { laboratories }\end{array}$ & Gas leak, injury & $\begin{array}{l}4 \times 3=12 \\
\text { Medium }\end{array}$ & $\begin{array}{l}\text { It should be made sure } \\
\text { that the gas is turned off } \\
\text { after becks are used, } \\
\text { warning signs should be } \\
\text { put for reminding, and the } \\
\text { environment should be } \\
\text { ventilated with specific } \\
\text { intervals. }\end{array}$ \\
\hline 27 & $\begin{array}{l}\text { Some of the } \\
\text { becks in the } \\
\text { laboratory being } \\
\text { located in front of } \\
\text { sockets }\end{array}$ & $\begin{array}{l}\text { Explosion, } \\
\text { injury, death }\end{array}$ & $\begin{array}{c}4 \times 5=20 \\
\text { High }\end{array}$ & $\begin{array}{l}\text { Becks where electric } \\
\text { sockets and cables are } \\
\text { located should be } \\
\text { removed. }\end{array}$ \\
\hline
\end{tabular}




\begin{tabular}{|c|c|c|c|c|}
\hline 28 & $\begin{array}{l}\text { Cracks on the } \\
\text { stairs of the } \\
\text { patient entrance } \\
\text { door and } \\
\text { level difference } \\
\text { on the floor and } \\
\text { no anti-slip tapes }\end{array}$ & Fall, injury & $\begin{array}{l}4 \times 3=12 \\
\text { Medium }\end{array}$ & $\begin{array}{l}\text { Level differences on the } \\
\text { stairs should be removed } \\
\text { and they should be } \\
\text { checked regularly, anti- } \\
\text { slip tapes should be put on } \\
\text { the steps }\end{array}$ \\
\hline 29 & $\begin{array}{l}\text { No safety net in } \\
\text { stair openings }\end{array}$ & Fall, injury & $\begin{array}{c}5 \times 3=15 \\
\text { High }\end{array}$ & $\begin{array}{l}\text { Death and serious injury } \\
\text { that may occur in case of a } \\
\text { fall should be prevented } \\
\text { by putting safety nets in } \\
\text { stair openings. }\end{array}$ \\
\hline 30 & $\begin{array}{c}\text { Hazardous } \\
\text { medical waste }\end{array}$ & $\begin{array}{c}\text { Infection } \\
\text { transmission }\end{array}$ & $\begin{array}{c}5 \times 4=20 \\
\text { High }\end{array}$ & $\begin{array}{l}\text { Accumulation, regular } \\
\text { collection, } \\
\text { Transportation and } \\
\text { temporary storage } \\
\text { procedures should be } \\
\text { carried out by authorized } \\
\text { personnel. }\end{array}$ \\
\hline 31 & Latex glove use & Latex allergy & $\begin{array}{l}5 \times 2=10 \\
\text { Medium }\end{array}$ & $\begin{array}{l}\text { Hypoallergenic gloves } \\
\text { should be used, stocks } \\
\text { should be checked. }\end{array}$ \\
\hline 32 & Chemicals & $\begin{array}{l}\text { Injury, allergic } \\
\text { reaction }\end{array}$ & $\begin{array}{c}4 \times 2=8 \\
\text { Medium }\end{array}$ & $\begin{array}{l}\text { Chemicals should be kept } \\
\text { under suitable conditions, } \\
\text { importance should be } \\
\text { given to EPE use, and } \\
\text { materials should be used } \\
\text { in accordance with safety } \\
\text { information forms. }\end{array}$ \\
\hline 33 & $\begin{array}{l}\text { Hazardous } \\
\text { carcinogen- } \\
\text { mutogenic } \\
\text { materials used in } \\
\text { prosthesis } \\
\text { laboratories } \\
\text { (acrylic, cast and } \\
\text { polish dust, } \\
\text { battery, } \\
\text { fluorescence, } \\
\text { etc.) }\end{array}$ & $\begin{array}{l}\text { Allergic } \\
\text { reaction, } \\
\text { occupational } \\
\text { diseases }\end{array}$ & $\begin{array}{c}5 \times 4=20 \\
\text { High }\end{array}$ & $\begin{array}{l}\text { Personal protective } \\
\text { equipment should be } \\
\text { used, there should be } \\
\text { ventilation system } \\
\text { (natural/artificial), } \\
\text { chemicals should be used } \\
\text { in accordance with } \\
\text { instructions, a hood with } \\
\text { vacuum feature or a } \\
\text { similar system should be } \\
\text { installed in order not to be }\end{array}$ \\
\hline
\end{tabular}




\begin{tabular}{|c|c|c|c|c|}
\hline & & & & $\begin{array}{l}\text { exposed to harmful } \\
\text { emission where chemical } \\
\text { substances that may cause } \\
\text { harmful emission such as } \\
\text { gas or dust are left in the } \\
\text { open, chemicals which are } \\
\text { not dangerous or less } \\
\text { dangerous should be used } \\
\text { instead of dangerous } \\
\text { chemicals. }\end{array}$ \\
\hline 34 & $\begin{array}{l}\text { Hazardous } \\
\text { carcinogen- } \\
\text { mutogenic } \\
\text { materials used in } \\
\text { polyclinics } \\
\text { (amalgam, } \\
\text { mercury, battery, } \\
\text { fluorescence, } \\
\text { disinfectant) }\end{array}$ & $\begin{array}{l}\text { Allergic } \\
\text { reaction, } \\
\text { occupational } \\
\text { diseases }\end{array}$ & $\begin{array}{c}5 \times 4=20 \\
\text { High }\end{array}$ & $\begin{array}{l}\text { Personal protective } \\
\text { equipment should be } \\
\text { used, which are not } \\
\text { dangerous or less } \\
\text { dangerous should be used } \\
\text { instead of dangerous } \\
\text { chemicals. }\end{array}$ \\
\hline 35 & $\begin{array}{c}\text { Flooding in } \\
\text { sterilization area }\end{array}$ & Slipping-falling & $\begin{array}{c}3 \times 3=9 \\
\text { Medium }\end{array}$ & $\begin{array}{l}\text { Devices that may have } \\
\text { water leakage should be } \\
\text { controlled periodically; } \\
\text { drains should be made to } \\
\text { prevent water } \\
\text { accumulation on the } \\
\text { ground. }\end{array}$ \\
\hline 36 & $\begin{array}{l}\text { Eating in the } \\
\text { working } \\
\text { environment }\end{array}$ & $\begin{array}{l}\text { Being exposed } \\
\text { to biological } \\
\text { risks }\end{array}$ & $\begin{array}{l}3 \times 4=12 \\
\text { Medium }\end{array}$ & $\begin{array}{l}\text { Training should be given } \\
\text { to employees and warning } \\
\text { signs should be put in } \\
\text { these areas. }\end{array}$ \\
\hline 37 & Unfixed cabinets & $\begin{array}{l}\text { Injuries as a } \\
\text { result of the } \\
\text { cabinets being } \\
\text { overturn }\end{array}$ & $\begin{array}{l}4 \times 3=12 \\
\text { Medium }\end{array}$ & $\begin{array}{l}\text { In the event of an } \\
\text { earthquake, cabinets that } \\
\text { are not fixed may } \\
\text { overturn and cause } \\
\text { injuries, so the cabinets } \\
\text { should be fixed. }\end{array}$ \\
\hline
\end{tabular}




\begin{tabular}{|c|c|c|c|c|}
\hline 38 & $\begin{array}{l}\text { Wearing } \\
\text { jewellery }\end{array}$ & $\begin{array}{l}\text { Being exposed } \\
\text { to biological } \\
\text { risks }\end{array}$ & $\begin{array}{c}4 \times 4=16 \\
\text { High }\end{array}$ & $\begin{array}{l}\text { Since rings worn while } \\
\text { working may cause glove } \\
\text { puncture and necklaces } \\
\text { and bracelets may cause } \\
\text { contact with body fluids, } \\
\text { employees should be } \\
\text { informed on this issue. }\end{array}$ \\
\hline 39 & Bantering & Work accident & $\begin{array}{c}4 \times 4=16 \\
\text { High }\end{array}$ & $\begin{array}{l}\text { One of the biggest factors } \\
\text { in the occurrence work } \\
\text { accidents is unsafe } \\
\text { behavior. Employees } \\
\text { should avoid unsafe } \\
\text { behaviors not to cause } \\
\text { work accidents. }\end{array}$ \\
\hline 40 & $\begin{array}{l}\text { Staff wearing } \\
\text { loose and } \\
\text { hanging clothes }\end{array}$ & $\begin{array}{l}\text { Being exposed } \\
\text { to biological } \\
\text { risks }\end{array}$ & $\begin{array}{l}3 \times 4=12 \\
\text { Medium }\end{array}$ & $\begin{array}{l}\text { Wearing loose or hanging } \\
\text { clothes while working } \\
\text { may cause contact with } \\
\text { body fluids and biological } \\
\text { risks. For this reason, } \\
\text { employees should wear } \\
\text { hospital uniforms and } \\
\text { aprons. }\end{array}$ \\
\hline 41 & $\begin{array}{l}\text { Waxes used in } \\
\text { preclinical } \\
\text { laboratories }\end{array}$ & Slipping-falling & $\begin{array}{c}5 \times 3=15 \\
\text { High }\end{array}$ & $\begin{array}{l}\text { It should be ensured that } \\
\text { the waxes used by our } \\
\text { students are scraped from } \\
\text { the ground after class. }\end{array}$ \\
\hline 42 & $\begin{array}{c}\text { Insufficient } \\
\text { ventilation in } \\
\text { patient } \\
\text { admission and } \\
\text { registration area }\end{array}$ & $\begin{array}{l}\text { Infection risk, } \\
\text { being exposed } \\
\text { to biological } \\
\text { risks }\end{array}$ & $\begin{array}{c}5 \times 4=20 \\
\text { High }\end{array}$ & $\begin{array}{l}\text { Artificial ventilation } \\
\text { should be used in areas } \\
\text { where natural ventilation } \\
\text { is insufficient; these } \\
\text { systems should be } \\
\text { checked and cleaned } \\
\text { periodically. }\end{array}$ \\
\hline
\end{tabular}




\begin{tabular}{|c|c|c|c|c|}
\hline 43 & $\begin{array}{l}\text { Scattered } \\
\text { cleaning } \\
\text { materials in } \\
\text { toilets }\end{array}$ & $\begin{array}{l}\text { Tripping, } \\
\text { falling }\end{array}$ & $\begin{array}{c}3 \times 3=9 \\
\text { Medium }\end{array}$ & $\begin{array}{l}\text { Materials should be put } \\
\text { back to their places after } \\
\text { cleaning. }\end{array}$ \\
\hline 44 & $\begin{array}{l}\text { Is wax melting } \\
\text { device used in } \\
\text { accordance with } \\
\text { Instructions of } \\
\text { use? }\end{array}$ & $\begin{array}{l}\text { Hot surface, } \\
\text { burning, injury }\end{array}$ & $\begin{array}{c}3 \times 3=9 \\
\text { Medium }\end{array}$ & $\begin{array}{l}\text { Waxing machine should } \\
\text { be used in accordance } \\
\text { with instructions of use } \\
\text { and by authorized } \\
\text { individuals, it should be } \\
\text { checked periodically and } \\
\text { there should be warning } \\
\text { signs on the device. }\end{array}$ \\
\hline 45 & $\begin{array}{l}\text { Is flask boiling } \\
\text { device used in } \\
\text { accordance with } \\
\text { Instructions of } \\
\text { use? }\end{array}$ & $\begin{array}{l}\text { Hot surface, } \\
\text { burning, injury }\end{array}$ & $\begin{array}{c}3 \times 3=9 \\
\text { Medium }\end{array}$ & $\begin{array}{l}\text { The device should be used } \\
\text { in accordance with } \\
\text { instructions of use and by } \\
\text { authorized individuals, it } \\
\text { should be checked } \\
\text { periodically and there } \\
\text { should be warning signs } \\
\text { on the device. }\end{array}$ \\
\hline 46 & $\begin{array}{l}\text { Is pressurized } \\
\text { acrylic baking } \\
\text { oven used in } \\
\text { accordance with } \\
\text { İnstructions of } \\
\text { use? }\end{array}$ & $\begin{array}{l}\text { Hot surface, } \\
\text { burning, } \\
\text { injury, } \\
\text { explosion }\end{array}$ & $\begin{array}{c}3 \times 3=9 \\
\text { Medium }\end{array}$ & $\begin{array}{l}\text { The device should be used } \\
\text { in accordance with } \\
\text { instructions of use and by } \\
\text { authorized individuals, it } \\
\text { should be checked } \\
\text { periodically and there } \\
\text { should be warning signs } \\
\text { on the device. }\end{array}$ \\
\hline 47 & $\begin{array}{l}\text { Is the solution in } \\
\text { which sharp } \\
\text { objects are put } \\
\text { kept in lidded } \\
\text { containers? }\end{array}$ & $\begin{array}{c}\text { Risk of } \\
\text { infection }\end{array}$ & $\begin{array}{c}\text { 4x4=16 } \\
\text { High }\end{array}$ & $\begin{array}{l}\text { Infected instruments used } \\
\text { in clinics should be put in } \\
\text { appropriate dirty } \\
\text { instrument boxes with } \\
\text { enzymatic solution with a } \\
\text { lid and strainer } \\
\text { immediately after use. } \\
\text { These instruments should } \\
\text { be transferred } \\
\text { immediately to central } \\
\text { sterilization unit with } \\
\text { suitable } \\
\text { containers/instrument } \\
\text { carrier lifts and measures } \\
\text { of each instrument per } \\
\text { patient should be made } \\
\text { through automation. }\end{array}$ \\
\hline
\end{tabular}




\section{Conclusion and Discussion}

Risk analysis and risk management process includes the process of identifying existing or potential hazards, evaluating the risks that may occur as a result of these hazards and working with a solution-oriented approach. This process is even more comprehensive in health institutions which have a complex working system because when risk analysis was evaluated and researches were examined, it was found that the degree of hazard in health institutions differed according to the work done, the qualification of the personnel and the working environment. At the same time, these hazards are a risk not only for the working personnel, but also for patients and their relatives.

Risk analysis and risk management process includes the process of identifying existing or possible hazards, evaluating the risks that may arise as a result of these hazards, and working with a solution focus. In health organizations that have a complex work system, this process is more comprehensive. Because when the risk analysis was evaluated and the research was examined, it was found that the degree of hazards in health institutions differed according to the work done, the nature of the staff and the working environment. As can be seen from Emine Esen Özyurt's study, the ease of access to hospital and health sector services has led to an increase in demand for these areas. This leads to increased workload and shows that hazards can pose a risk not only to working staff, but also to patients and relatives of patients [13].

A study conducted at ADB found that employees in the health sector experience injuries due to 600,000 cutting - piercing tools every year. Because the source of infection in such injuries is cutting - piercing materials that come into contact with the patient, the incidence of diseases transmitted by body fluids and blood, especially hepatitis B and HIV, is very high. In research conducted worldwide, 344 health professionals had occupational HIV infection, 106 of which were unproven, 238 of which were registered as suspicious. In addition to these diseases, transmission has been observed through respiration and droplets. Research conducted throughout our country has shown that the incidence of turbercrosis in society was 34 per 100,000, while in health workers, this figure was 96 per 100,000 [14].

Another common risk element in dentistry is chemicals. Mercury, especially used as an amalgam substance, is the most common chemical in dentistry. Exposure to Mercury occurs due to manual contact or inhalation. Most of the time, Mercury material is spilled and splashed on the ground, or damaged amalgamators are the cause of contamination. Because Mercury, which is mostly used in the restoration process, is an extremely toxic substance, it causes poisoning when exposed too much. It is also possible to use a less toxic material instead of mercury material using the substitution method. But, as Seval Bilmen explained in his study, Mercury is more preferred due to reasons such as staying in the mouth for a long time, easy sitting on the edges of the teeth, less secondary caries, more resistant to the pressure associated with chewing [15]. 
The fact that mercury is very preferred in dentistry has also led to the start of studies on Mercury hygiene. The American Dental Association (ADA) set out the issues that health professionals and assistants working in dental clinics or hospitals should pay attention to about Mercury hygiene at a council meeting in 1999, but failed to establish a standard rule. Currently, the substances that remain valid are as follows; [16]

\section{New information must be constantly followed.}

2. Carpet flooring should not be used where mercury will drip or splash.

3. As much mercury as possible should not be spilled on the ground.

It was observed that some of the other hazards determined could be due to structural problems resulting from buildings and extensions, while some others could be due to unsafe situations and behaviors (bantering, wearing jewellery, eating in the working environment, etc.). In order to reduce the existing hazards or to prevent the potential hazards, all personnel should be trained, health screenings should be made, periodical controls should not be delayed and vaccinations should be made. In the disposal of wastes, infrastructure should be provided for separation at source and this procedure should be provided by the authorized personnel. While using chemicals, material safety data sheet should be provided and they should be used and stored according to these forms. Limit values specified in the regulation should be followed in all working areas, there should be personal protective equipment suitable for the work done and their use should be followed.

The information obtained as a result of the study conducted has shown that occupational health and safety studies should be included in the working process from the start. It is thought that planning and carrying out a joint work plan with job health and safety in all areas from the foundation phase of the building to the selection of the place, from the selection of the equipment used to their maintenance, control and follow up, from selecting to qualified personnel to the number of personnel required, in all areas affecting the process from the beginning to the end will both enable the prevention of big scaled hazards and also help in preventing work accidents and occupational diseases and contribute to decreasing time loss and eventually provide positive contributions to employees, the institution and everyone receiving service in this field. 


\section{References}

1. TMMOB makine mühendisleri işçi sağlığı ve iş güvenliği oda raporu, Ankara; 2016.

2. Yassi A, Tate R, Cooper J, Jenkins J, \& Trottier J, Causes of staff abuse in health care facilities: Implications For Prevention. AAOHN Journal, 1998; 46(10): 484491.

3. European agency for safety and health at work (EU-OSHA), [Erişim tarihi: 07 Mart 2020] Erişim adresi, http://osha.europa.seu.

4. Küçükeşmen Ç, Dental amalgamın insan organizması üzerindeki etkileri, Süleyman Demirel Üniversitesi Tıp Fakültesi Dergisi, Isparta, 2007; (3): 52.

5. Bilmen S, Diş hekimliğinde civa kullanımı ve civa toksisitesi, Ege Üniversitesi Diş Hekimliği Fakültesi Bitirme Tezi, İzmir, 2008.

6. Başak S, Diş hekimlerini etkileyebilecek fiziksel risk etmenleri, Gümüşhane Üniversitesi Sağlık Bilimleri Dergisi, 2018;7(1):184-192.

7. Szymańska, J, Dentist's hand symptoms and high-frequency vibration, Ann Agric Environ Med, 2001:8.

8. Saygun M, Sağlık çalışanlarında iş sağlığı ve güvenliği sorunları, TSK Koruyucu Hekimlik Bülteni, 2012; 11(4): 373-382.

9. Karim N, Choe CK, Laboratory accidents--a matter of attitude. The Malaysian Journal of Pathology. 2000; 22(2): 85-89.

10. Aksakal FN, İlhan MN, Yüksel H, Kurtcebe Ö, Bumin MA, Bir üniversite hastanesinde hemşire, sağlık memuru ve hastabakıcılarda bel ağrısı sıklığı ve etkileyen faktörler, Mesleki Sağlık ve Güvenlik Dergisi, 2009; 32: 38-46.

11. Myers HL and Myers LB, It's difficult being a dentist': Stress and health in the general dental practitioner, Br Dent J, 2004; 197: 89-93.

12. Özkılıç Ö, İş sağlığı ve güvenliği, yönetim sistemleri ve risk değerlendirme metodolojileri, Ankara, 2005: 67.

13. Özkılıç Ö, İş sağlı̆̆ı ve güvenliği, yönetim sistemleri ve risk değerlendirme metodolojileri, Ankara, 2005: 113-115.

14. Özyurt Emine E, Sağlık sektöründe risk analizi, risk yönetimi ve ağız, diş sağlı̆̆ı merkezlerinde risk, Yüksek Lisans Tezi, İstanbul, 2014

15. Sağlık çalışanlarının meslek riskleri, Türk Tabipler Birliği Yayınları, Ankara, 2008: 9-10.

16. Bilmen, S, Diş hekimliğinde civa kullanımı ve civa toksisitesi, Ege Üniversitesi Diş Hekimliği Fakültesi, Bitirme Tezi, 2008.

17. JADA, 2003, november,vol:134 